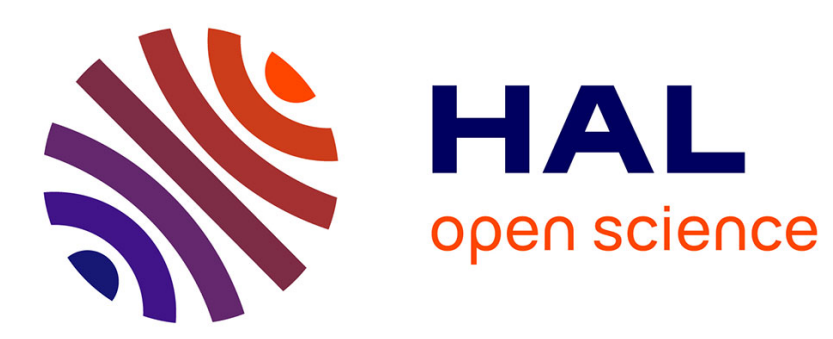

\title{
Revisiting Slavery and the Slave Trade in Ethiopia
}

Giulia Bonacci, Alexander Meckelburg

\section{To cite this version:}

Giulia Bonacci, Alexander Meckelburg. Revisiting Slavery and the Slave Trade in Ethiopia. Northeast African Studies, 2017, 17 (2), pp.5-30. 10.14321/nortafristud.17.2.0005 . hal-02306643

\section{HAL Id: hal-02306643 \\ https://hal.science/hal-02306643}

Submitted on 25 Aug 2021

HAL is a multi-disciplinary open access archive for the deposit and dissemination of scientific research documents, whether they are published or not. The documents may come from teaching and research institutions in France or abroad, or from public or private research centers.
L'archive ouverte pluridisciplinaire HAL, est destinée au dépôt et à la diffusion de documents scientifiques de niveau recherche, publiés ou non, émanant des établissements d'enseignement et de recherche français ou étrangers, des laboratoires publics ou privés. 


\title{
Revisiting Slavery and the Slave Trade in Ethiopia
}

\author{
GIULIA BONACCI, Institut de Recherche pour le Développement, URMIS, Nice \\ Alexander Meckelburg, Hiob Ludolf Center for Ethiopian Studies, \\ University of Hamburg
}

\section{ABSTRACT}

Slavery remains one of the blind spots in the historiography of the Horn of Africa in general and Ethiopia in particular. This is peculiar in light of the fact that in the territories of the Horn slavery left a significant imprint on the sociocultural fabric, and that the ports along the Horn of Africa coast fed the slave trade to the Arab, Ottoman, and Indian Ocean worlds for many centuries. In this article, we highlight some of the research trends on slavery in Africa and discuss slavery and the slave trade in different Ethiopian regions. We also question the public silence around the legacies of slavery in the country. By means of introducing the articles of this special issue, we point towards new, pending, or unresolved research questions.

\section{Slavery Studies and Africa}

In slavery studies, the areas most represented are North and South America (United States, Brazil), and the Caribbean region (insular and coastal). Since the pioneering work of W. E. B. Du Bois, Eric Williams, Pierre Verger, Philip Curtin, and Orlando Patterson, historical, anthropological, economic,

Northeast African Studies, Vol. 17, No. 2, 2017, pp. 5-30. ISSN 0740-9133. ๑ 2017 Michigan State University. All rights reserved. 
political, literary, and artistic enquiries on Atlantic and American slavery have demonstrated ongoing dynamism and maturity. ${ }^{1}$ In 1979, Frederick Cooper noted that Africanist research was largely "anxious to disassociate slavery in Africa from its bad image in the Americas." ${ }^{2}$ As a matter of fact, the dominance of the Atlantic model, supported by the accessibility of primary sources including a number of exhaustive databases ${ }^{3}$ was challenged by a growing scholarship on slavery in Africa, i.e., on the slave systems internal to African societies. Since the work of Suzanne Miers and Igor Kopytoff, Claude Meillassoux, and Paul Lovejoy, the longue durée of the history of internal slavery in Africa is firmly established. ${ }^{4}$

In the last three decades, a number of detailed monographs have improved our knowledge of slavery in Africa and of the challenges of emancipation in the twentieth century, in particular in the West African region. Authors like Martin Klein, Roger Botte, or Benedetta Rossi, among many others, have been instrumental in this regard. ${ }^{5}$ In North Africa and the Middle East, the enslavement of sub-Saharan Africans, once nearly invisible, is now coming to the fore. ${ }^{6}$ The Central African region remains underrepresented in the field despite some groundbreaking works. ${ }^{7}$ In East Africa and on the Swahili coast, slavery studies were launched thanks to the work of Edward Alpers and Frederick Cooper, ${ }^{8}$ followed by a few others, including Laura Fair and Elisabeth McMahon. ${ }^{9}$ Although there is a social reluctance to face slavery in Kenya, and although the political mobilization of slave descendants is not as prevalent as in West Africa, recent works on issues of resistance and emancipation portray the civil societies' claims in relation to inherited slave status. ${ }^{10}$ In fact, attention to the legacies of slavery in contemporary Africa, and to the struggle of slave descendants for citizenship rights is fueling new research on African societies. ${ }^{11}$ In addition, a recent trend in Kenya is to institutionalize the tangible heritage of slavery with the aim of promoting tourism among concerned communities. ${ }^{12}$

In this context of significant growth of the literature on slavery in Africa, Ethiopia remains a blind spot. Despite Ethiopia's remarkable involvement in the global slave trade, and slavery's structuring impact on social relations in the country, the historical patterns of slavery and their contemporary consequences remain largely unaddressed in Ethiopian studies. The literature on Ethiopia offers multiple mentions of the practice of slavery but does not 
grant it much critical attention. The foundational studies, published between the 1960s and the 1980s, are few and scattered. They are largely descriptive and tend to focus on the trading dimension rather than on the multiple systems of slavery that coexisted in Ethiopia. ${ }^{13}$

Sources may seem scarce for medieval Ethiopia up to the eighteenth century (see Ayda Bouanga in this volume), but they are abundant for the nineteenth and twentieth centuries, with a significant input made by colonial-era writings. Many important contributions use specifically British documentation to back their arguments. ${ }^{14}$ Ethiopian sources, replete with references to slavery, need to be read anew in order to produce alternative narratives and perspectives on the practices of slavery and slave trading, and on their historical significance. ${ }^{15}$ In fact, in this special issue, Hagar Solomon analyzes proverbs as alternative sources, Peter Garretson sheds new light on Ethiopian abolitionism thanks to little-known private sources, and Alexander Meckelburg and Solomon Gebreyes give attention to the context of an overlooked British document of 1884 in Amharic. A young generation of scholars has begun to produce new and challenging case studies, but much remains to be accomplished in order to add quantitatively and qualitatively to our understanding of the multifaceted dynamics of this phenomenon as it operated in Ethiopia and the Horn. ${ }^{16}$ For example, the precious attention now given to the memories of former slaves or of slave descendants does not yet inform the national discourse. ${ }^{17}$ To make such an impact would entail acknowledging the ways in which slavery frames today's social fabric, and in particular how it influences the interethnic relations between former slaves and their descendants on the one hand, and former masters and their descendants on the other. We may ask: could today's Ethiopia be analyzed as a "post-slavery society," like other African, European, or American societies? The term "post-slavery" refers to the historical and social circumstances identifiable "in contexts where slavery was a fundamental social institution and its legal abolition was followed by resilient legacies of past hierarchy and abuse." ${ }^{18}$ Can we document the relation between past evidence of slavery and contemporary patterns of discrimination, exclusion, and servitude in Ethiopia? The absence of any discourse - scientific or public — on Ethiopia's past with regard to slavery should indeed be addressed. In this introduction, we give a brief overview 
of the literature related to slavery and to the end of slavery in Ethiopia before introducing the articles of this special issue.

\section{The Contours of the Study of Slavery in Ethiopia}

An overview of the intertwined topics of slavery and the slave trade needs to be chronological, thematic, and regional. A brilliant example is produced by Henri Médard who assesses the state of knowledge on slavery and slave trade in the East African region and the Indian Ocean. ${ }^{19}$ Some of the themes he tackles, like the influence of slaves on the modes of production, the abolition of slavery, slave resistance, and identities (gender, ethnicity, diaspora) could structure any enquiry on slavery in Ethiopia. Most of the examples he relies on are drawn from the Swahili coast, Central Africa, Mozambique, the Cape Colony, and the Indian Ocean islands (Madagascar, Mascareignes, Seychelles); Médard also acknowledges how limited is the research on slavery in Ethiopia. ${ }^{20}$ What his approach illustrates is that Ethiopia would "fit" neatly in a regional approach, and Ethiopia's historical characteristics should be articulated in reference to the wider patterns of slavery and slave trade in Eastern Africa. In fact, any research on the topic should deepen case studies and local situations, without losing sight of the wider context, issues, and patterns.

The Encyclopaedia Aethiopica offers a comprehensive overview of sources and issues related to slavery and the slave trade in Ethiopia in five subsections: "Slave trade from ancient times to 19th century"; "Red Sea slave trade in the 19th century"; "Slave raiding in the 19th century"; "Domestic slaves and court slavery"; and "The slavery question in politics." ${ }^{21}$ The articles summarize the recent state of knowledge of this complex field and the various issues that arise from the study of the institutions of slavery and slave trade in Ethiopia. They highlight the antiquity of the trade in slaves from the region: Pliny mentioned slave exports from the Aksumite port of Adulis, and the Periplus of the Erythraean Sea reports on the shipment of slaves from the ports of the Gulf of Aden. According to the Egyptian traveler Cosmas Indicopleustes in the early sixth century, most slaves exported from the Ethiopian region came from "Sasu, perhaps the inland country south of 
the Blue Nile."22 Arab writers from the tenth to the twelfth century like Ibn Hawqal and al-Maqrizi report on slaves being received by the king of Yemen; and slaves are identified as "some of the principal merchandise of Aden."23 The question of the existence and the survival of an Ethiopian slave diaspora in the Indian Ocean is not resolved, despite noteworthy works on the issue. ${ }^{24}$ The centuries-old presence of black people in Oman, in India, where they are called "Habshi" or "Sidi," or in South East Asia, testifies to the complexity of the dispersion in the Indian Ocean. ${ }^{25}$ Ethiopia connected the Nile Valley with the maritime space and was a hub for the Red Sea and the Indian Ocean trades, and for the Ottoman world. There were three main outlets for slaves in Ethiopia: Mätämma on the Sudanese border, Massawa catering for the Red Sea trade, and Tağūra for the Indian Ocean. ${ }^{26}$

In the larger East African region, the nineteenth century saw a dramatic increase in the volume of the Red Sea and Indian Ocean trades, as the region became more closely integrated into global commercial structures. ${ }^{27}$ As a corollary to the increasing volume of the trade, the nineteenth century witnessed as well a sharp increase in documentary sources on slavery, and in particular of colonial sources. Although these have to be taken with precaution and contextualized within the dominant discourses of abolitionism for humanitarian or colonialist purposes, it is not surprising that Western missionaries took interest in the slaves. Memoirs of manumitted slaves taken into missionary service are some of the most intimate sources we can find on the condition of slaves in Ethiopia. ${ }^{28}$ Travelers and diplomats observed the changing configuration of a number of polities that were directly threatened by the expansion of the Ethiopian empire and suffered from the violent raids of soldiers taking away people to enslavement. ${ }^{29}$

There is a tendency to assign to Muslims a major responsibility in the development of slavery and slave trade since medieval times. In fact, Muslims represent a convenient screen behind which other actors can hide..$^{30}$ As the coast of the Red Sea, the Gulf of Aden and the port of Zayla' were under the authority of Muslim sultanates, there can be little doubt about the involvement of Muslim traders in this commerce (see Bouanga in this issue). In the nineteenth century, though, the emphasis of European travelers and abolitionists on the demand for slaves in the Arab world, and on the role of Muslim traders in meeting that demand, is evidence of their bias against 
Muslims, with a racial tinge. For example, upon his visit to Tağūra, traveler Charles Johnston concluded, "the male inhabitants of Tajourah have no other occupation than the traffic in slaves. ..."31 British diplomat Walter Plowden characterized the Muslim slave traders of Massawa as living "entirely by their trade with the Abyssinians in slaves and other articles of commerce, and are fanatical Mahomedans." ${ }^{32}$ However, groundbreaking research on fifteenth and sixteenth century Ethiopian Christian literature demonstrates that Christians too were involved in the production, consumption, and the trade of slaves. Therefore, slavery should be understood as a system in which Christians and Muslims participated for both competing and shared interests. $^{33}$

Various other polities and kingdoms in the Ethiopian region practiced slavery and participated in the slave trade. For example, the Omotic kingdoms and the Gibe states of the south were already slave-holding societies long before their integration in the Ethiopian kingdom: "Wälaytta royal officers, slaves by their nominal status, served as majordomos and treasurers of the kawa (king). ${ }^{34}$ In the kingdom of Käffa, the state involvement in the slave trade was such that the king institutionalized an office to oversee the slave trade, the guğe rašo, the "Sklaven-Vogt ("slave governor"). ${ }^{35}$ Among the Haddiya, former specialists of the production of eunuchs for the international trade, the redemption of the slaves "could be achieved by extraordinary merits... If their owners agreed, slaves could participate in warfare and also carry the insignia of killers." ${ }^{36}$ However, examples of slaves reaching to high positions does not indicate the flexibility of the slave system, but rather, as Frederick Cooper underlined, its failure, i.e., the inability of slave owners to control their subordinates. ${ }^{37}$

In this complex system, the definition of who was a slave, what enslavement entailed, and what the other social and legal statuses of dependency were is indeed central. This is a particularly arduous question in the Ethiopian region. Research on sixteenth-century Ethiopia showed how the Ge'ez term gabr was translated as slave. ${ }^{38}$ The first meaning of $g a b r$ is actually servant, and peasants were then called gäbbar, a class of people who only had usufruct of the land and had to pay tribute to landlords. The blurring of meanings between slave and gabr points to the imbrication of landrelated status and servitude, a topic only recently explored in the literature. ${ }^{39}$ 
Although there is a marked difference between a captive (dewew), a war prisoner, a slave ( $\mathrm{gabr}$ ), and a slave at the court, it is interesting to note a distinction between gabr (a male servant or slave) and 'amat (a female servant or slave), sometimes called garad as well. This points to a complex gender-based set of dependency statuses.

With the southern conquests of Emperor Mənilək II at the end of the nineteenth century, the gäbbar system, peculiar to the northern highlands of the country, was harshly imposed on southern territories and societies. ${ }^{40}$ Forms of nonfree labor did exist in these southern areas prior to the expansion of Ethiopian imperial rule; however, the implementation of the gäbbar system, the "unremitting exploitation of the peasantry," "operated as the mechanism by which the ruling class appropriated the surplus of the peasants' produce. ${ }^{\prime 41}$ Peter Garretson studied the case of the Maji areas, ${ }^{42}$ and recently Alexander Meckelburg and Abdussamad Ahmad demonstrated how the gäbbar system and its associated imposition of tax and tributes actually fueled the trade in humans in Bela Šangul. When Bela Šangul was conquered by the Ethiopian troops led by Ras Mäkwännən, šayh Hwağalī al-Hasan managed to become the administrator of the tributes paid to Addis Ababa annually. The tribute extraction accelerated the local systems of slavery as children were often handed over in lieu of tax. Child tributes were levied on lesser landlords of the region, and on the subordinate peasant population unable to pay tax in another form. ${ }^{43}$ With the center demanding all sorts of tributes, šayh Hwağali increasingly raided the population, and he "revived the slave raiding and hunting, and gold mining using slave labor." ${ }^{44}$ Bahru Zewde measured the increasingly exploitive forms of this central Ethiopian institution and concluded that "cultural oppression was coupled with economic exploitation.. ${ }^{45}$ The paradigm of the gäbbar system overrode earlier characteristics and stakes of slavery in areas historically prone to slave extraction. And what numerous scholars did identify as feudalism, serfdom, or exploited peasantry further blurred the distinction among slaves, peasants, and dependency statuses related to land. We can only follow Donald Crummey, who remarked: "with respect to the question of basic class relations, in a very general way the cultivators occupy vaguely comparable positions in the two social formations on the continuum running from slavery to wage labor." ${ }^{\text {46 }}$ 
With the expansion of the Christian empire, the state "became the largest owner of slaves in the country" and used slaves as laborers in its palaces, on the fields and farms ${ }^{47}$ But individual soldiers or armed men could also launch brutal raids in the frontier regions, or during periods of political instability, and make a living out of it. Aside from the Christian state, numerous Ethiopian societies were major actors in the production and trade of slaves, making slavery the matrix of many economic and cultural practices in the region. Many local rulers in the wider region lived off the taxation of trade routes, including the trade in slaves. What was attested for the Gibe kingdoms by Fernyhough holds true for the state of Käffa, the Oromo kingdoms of Leeqa Qälläm and Naqamtee, the sheikdoms of Beni Šangul, and many other chiefdoms and kingdoms that demonstrated some territorial control. Also, kings in the Ethiopian highlands gained revenues from the taxation of trade through their territory, like the kingdom of Šäwa. With the southern conquests of Mənilək II, the growing Ethiopian empire was able to connect to the slaving infrastructure, tax local trade, receive tributes in form of slaves, and benefit from slave labor in its peripheries. In addition, slaves were also used in all sorts of domestic labor in the houses of Ethiopian royalty, of Ethiopian nobility and more widely in other households, placing slavery in yet another perspective, that of domestic labor, still very much alive in the country today. It is quite ironic that the former slave quarters called Qera, located around Mənilək's Palace in Addis Ababa, were razed in the 1990s to make room for the construction of the first modern luxury hotel in Ethiopia, the Sheraton.

\section{The End of Slavery in Ethiopia}

The end of slavery is intimately related to the issue of dependency of a polity on slaves, and therefore can only be assessed once we understand whether Ethiopia was a society with slaves or a slave-based society (or a society composed of slave societies). ${ }^{48}$ Ğimma, the most powerful and ancient of the Gibe kingdoms, is an interesting case and some studies have looked at its slave economy using the observations of several nineteenth and twentieth century visitors. Ğimma exemplifies many of the contradictions intertwined 
with the study of slavery and the slave trade. ${ }^{49}$ Although Timothy Fernyhough argued that the control of the trade routes, including the slave trade, was "the primary cause for the expansion of the Gibe states," he added that none of the Gibe states relied solely on the export of slaves or on slave production. ${ }^{50}$ Tekalign Wolde Mariam, on the other hand, using an interpretation of a variety of oral and written sources, concluded that the economy of Ğimma was not based on "tolls and dues" from the slave trade, but instead that "slavery, as opposed to the slave trade, could be said to have occupied a crucial position in the economic system of the kingdom." ${ }^{51} \mathrm{He}$ characterizes Ğimma as a slave economy, "in which slave labor significantly affects the production process." ${ }^{52}$ The example of Ğimma raises several questions on the incorporation of slave production and labor in the expanding Ethiopian Empire, and on abolition and the end of slavery in Ethiopia as a whole. In fact, the abolition of slavery may have provided Haylä Śllase I with a pretext to annex the coffee-rich kingdom; but what was really at stake was the expansion of the market economy, and the rise of coffee as a major export crop in the 1920s..$^{53}$ The work of Jon Edwards is critical in this regard. He argues that the decline of slavery was the result of increasing wage labor. ${ }^{54}$ According to his argument, slaves became too expensive and consumed too much of the local surplus required to generate cash. Furthermore, "a considerable and log-term decline in the supply of slaves induced a slave-price inflation and encouraged a reorganization of the export economy from slaves to coffee and hides. ${ }^{55} \mathrm{At}$ this stage, the idea of a continuum between slavery and wage labor, in which the peasantry would be diversely placed depending on the region and the time period seems a solid hypothesis to pursue when enquiring about dependency statuses.

The use of sources produced in a politicized context makes the study of the abolition of slavery especially difficult, a concern that Guluma Gemeda pointed out regarding the inflated British public interest in slavery in Ethiopia in the 1920s when slavery was actually declining in the country. ${ }^{56}$ In the context of Ethiopia's application to membership in the League of Nations, most of the foreign sources have to be analyzed against their ideological and political bias. By the 1920s, slavery and its abolition had become a matter of international debate with geopolitical dimensions, an imbrication of various and conflicting imperatives that Suzanne Miers synthesized as follows: 
The French feared on the one hand that the British agitation was the prelude to an attack on Ethiopian independence, and on the other that a determined attack on slavery by the government of Ethiopia might provoke rebellion.... The Ethiopians thought membership in the League would ensure their continued independence, give them support against the British Tana demands and Italian economic and territorial ambitions, as well as end the slavery agitation. ... Britain strongly opposed Ethiopian admission to the League believing that its application was a French plot to flood the country with arms on the pretext that they were needed to fight slavery. The rationale for this was that, once admitted, Ethiopia could apply to be allowed to import arms under the Arms Traffic Convention like other governments. ${ }^{57}$

The international dimension of the abolition of slavery has fueled quite some research. ${ }^{58}$ At the same time, though, this focus has suppressed muchneeded research on the Ethiopian abolitionist agenda and the indigenous attempts to suppress slavery (see the contribution of Peter Garretson in this issue). ${ }^{59}$ In fact, the pattern of attempts to abolish slavery in Ethiopia has recently been dated back to the time of King Galawdewos, who issued a treaty to outlaw the trade of slaves through his dominions in the sixteenth century. ${ }^{60}$ But it was really only during the nineteenth century, with the international impact of Britain's abolition of the slave trade in 1807 and its application in 1812 in the Indian Ocean, ${ }^{61}$ that the abolition of slavery became a cause for political debate in Ethiopia. With the decline of the Ottoman Empire, slave trade was outlawed in the Red Sea thanks to a treaty signed between the British and Egypt in 1860. Emperor Yohannəs IV, representing Ethiopia, signed a first official anti-slavery treaty in 1884 as part of the peace negotiations with Egypt, under the influence of the British government (see Meckelburg and Solomon Gebreyes in this issue). Submitting to international demands, Mənilək II also committed to the abolition of the trade in humans at the beginning of his reign in the late nineteenth century.

This posture was reinforced by edicts signed by Ras Täfäri Mäkwännən, then regent of Ethiopia in 1924 and again in 1931-32. The 1924 edict was an important step to appease the Tripartite powers in Ethiopia's attempt to join the League of Nations. In 1931-32, Haylä Śllase I established an Anti-Slavery 
Department (headed by the Swiss advisor Frank De Halpert) and invited the chairperson of the British Anti-Slavery Society to Ethiopia in a move to pacify the concerns of the League of Nations. ${ }^{62}$ The Anti-Slavery Department was "to supervise the implementation of the slavery laws, to register slaves and look after those who were freed, as well as run a special police force and slavery

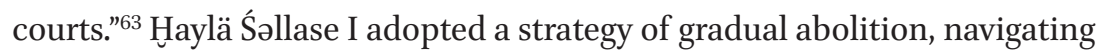
among the reluctance to pursue abolition by the privilege-owning classes (nobility, royalty, Church); the geopolitical implication of membership in the League of Nations; and the colonialist appetites of European powers.

However, the slavery courts functioned only until $1936^{64}$ and De Halpert withdrew disappointed, "finding his department at a standstill, and his advice unheeded." ${ }^{55}$ Although there were showcases against slave traders in some provinces ${ }^{66}$ the situation in the peripheral provinces remained unsatisfactory, at least in the eyes of Western abolitionists, as the state apparatus in the provinces was weak. ${ }^{67}$ In addition, local governors were themselves involved in the business of slavery. The governors of the provinces lived off the unpaid labor of the peasants and despite the efforts of the anti-slavery commission "took bribes and showed more zeal in punishing those who stole slaves from their masters than in meting out justice to slave dealers." ${ }^{\prime 6}$ In his discussion of abolition in northern Ethiopia, James McCann showed that freed slaves often formed a new labor force, termed yä zar barya (grass slaves). These freed slaves gave themselves into the service of officials who had freed them or, lacking oxen and seeds, had little choice but to join households for shelter and food, "a continuation not very different from that of slavery." 69

The overall situation and challenges to abolish slavery left much room for Italian agitation against the "last bulwark of slavery" and in favor of their "civilizing mission." ${ }^{.70}$ At the beginning of their rule the Italians set up socalled "freedom villages," in which they settled and supported freed slaves. ${ }^{71}$ Plenty of propaganda material appeared praising the humanist mission and forecasting the well-being that would be bestowed upon the slaves by the Italian presence. In some parts of Ethiopia, Italian authority ousted local governors and näfțäñ̃a, who were the staunchest opponents of abolition before 1935. In an interesting twist, though, Italians themselves were using forced labor in the attempt to exploit the mineral resources of the country, 
forcing corvée labor on the population, and caring little for the lives of the people they claimed to liberate. ${ }^{72}$ Furthermore, Ethiopian colleagues have hinted-in personal communications - that a major consequence of the Italians' abolitionist agenda was not so much to abolish slavery, but to push it further underground, making clandestine slavery undetectable in foreigners' gaze. Following the liberation of Ethiopia and the return of Hyaylä Śəllase I to the throne, a new edict reaffirmed the abolition of slavery in 1942. This date is usually seen as the official ending of slavery in Ethiopia.

But this is not the end of the story. What happened to the freedom villages? What happened to yä zar barya and to former slaves? And how do legacies of slavery continue to shape interethnic relations in today's post slavery society? In the 1980s, Igor Kopytoff questioned the disengagement of anthropologists in the study of slavery. ${ }^{73}$ And we may ask why, in light of so much existing data, no disciplines other than history have fully engaged in the study of slavery, the slave trade, and its legacies. Fortunately, some researchers, anthropologists and ethnohistorians are producing new data on slavery and its legacies in the region. Their approach represents a turning point in our understanding of slavery, in particular as Wendy James reminds us that: "The overwhelming majority of writings on slavery, whether empirical or theoretical in focus, have been biased in the sense that they have taken as their main field the slave holding society, and their main angle of view the perspective of the owners, or as sometimes expressed, the hosts of slaves." ${ }^{74}$

In fact, recent engagement with the history of slavery demonstrates that memories of slavery, if occulted in the public sphere, remain largely alive and accessible in the field. ${ }^{75}$ The use of oral history in crafting historical and contemporary narratives is no longer contested as a viable scholarly tool, and former slaves and their descendants do have a history, and more often than not are willing to share it. ${ }^{76}$ "Much historical information about ex-slaves and the transition to freedom is recoverable only in informal oral and life histories, or in uncovering symbolic or significant tidbits in daily conversations." ${ }^{77}$

Oral history allows new perspectives on the institutionalization of slavery, of its networks, of its markets and routes, and of its cultural practices in the Ethiopian region (see the article by Hagar Salamon in this issue). Orality 
and memory are inevitably shaped by current contexts and ideologies, and by the ethnopolitics ruling Ethiopians for the past thirty years. This context actually represents an additional rationale for the study of slavery and if not its end, its legacies. For example, Arnaud Kruczynski convincingly demonstrates how, during the second half of the nineteenth century, the label "guragué" designated a large proportion of the slaves sold in the highlands and beyond. The "guragué" slave acted as an archetype of the "red" slave, a person that would phenotypically look like the majority of the northern population. But rather than designating a specific set of people, or an ethnic group, this label was imposed on all the slaves who passed through the region named Guragué. This example deconstructs the usual representation of Guragué as a region and a people devastated by raids, razzias, and enslavement, and gives them agency as significant intermediary actors of the trade. Going a step further, Kruczynski explains how the popularity of "guragué" slaves surely prepared the ground for the enrollment and integration of migrant workers coming from the administrative region of Guragué in the major urban centers of the country in the early twentieth century. ${ }^{78}$

For medieval Ethiopia, it seems impossible to understand the human context of the slaves, their family ties or their absence, their inclusion or exclusion from society, their cultural otherness; ${ }^{79}$ but for the nineteenth century until today, it is certainly possible to get insights into the social life or death of a slave. For example, Bosha Bombe has explained how among the Ganta of the Gamo highlands, slave ancestry is experienced today through social deprivation and exclusion. Slave descendants can undergo redemption rituals (wozzo) that purify them from their slave ancestry and lift them out of the stigma of servitude in order to become part of mainstream society. Ritual experts and religious leaders conduct this redemption and make financial profit from those costly rituals involving the revitalization of cultural practices. ${ }^{80}$ Slavery is not only a southern concern. For example, in Goğğam, Laury Belrose collected testimonies of individuals on the labor of the slaves, whether agricultural or domestic, and about the promiscuity between slaves and masters. ${ }^{81}$ Oral history and memory represent a range of sources that once seen against the background of the numerous written sources, especially for the nineteenth and twentieth centuries, offer a vast landscape for further research. The state of slavery studies in the Ethiopian 
region could be summed up in the words of Donald Crummey: "The fields are ripe, the harvesters few." ${ }^{\prime 2}$

\section{Silence and Slavery}

As is often the case in many contemporary societies, slavery is an embarrassing topic as it encapsulates experiences of domination, exclusion, violence, and immorality. Through the twentieth century, various forces have worked in different ways but with the same objective: forget about slavery in Ethiopia. After the victory of Adwa in 1896 and the survival of Ethiopian independence, slavery became the ultimate tool with which European powers tried to impose their ideological agenda and their political influence. The British showed great concern for slavery and abolition but reacted only when the illicit slave trade crossed the borders of their colonial territories. The League of Nations deemed abolition a criterion for membership. Italian fascist propaganda heaped defamation on the last sovereign state of Africa as a prelude to the war of 1935-41. In turn, the Ethiopian crown and government officials had to find ways to silence slavery, and to cover it with a veil of secrecy.

Black intellectuals and activists in the Americas rejected the idea of slavery existing in Ethiopia: Ethiopia, the beacon of Pan-Africanism and the archetype of many black identities could not be a slave society. ${ }^{83}$ Slavery must belong only to European imperialism and the American plantations, and not to this territory, royalty, and lineage enshrined in the Bible. Following that logic, Ethiopia, a state that promoted and hosted the foundation of the Organization of African Unity in 1963, could not be associated with issues of servitude and exclusion. Even in the 1980s, when a military junta ruled the Ethiopian state, the Därg gave much attention to the tyranny of the former regime, and radically transformed the system of land tenure, but the complexities of local slaving societies were overshadowed by the "national question" and the liberation of cultures from the feudal order. Class distinctions as well as political affiliations obstructed the discussion on slavery. Ethiopian intellectuals, who have so often been at the forefront of social and political change, seem to be still refusing the idea that slavery 
was widespread in the country. The public sphere and the media give no room to questions about slavery and its legacies. The social, intellectual, and political reluctance of Ethiopia to address slavery forms a wall of silence around the role of slavery in shaping the country's social fabric and interethnic relations. What is the meaning of this silence? The reluctance to acknowledge the silence seems evidence in itself that much is to be found there, in the place that slavery holds at the sensitive core of Ethiopia's history and societies.

\section{The Contributions in this Special Issue}

This special issue is part of an ongoing collective scholarly initiative tying together slavery studies and Ethiopia. A number of research seminars and panels dedicated to slavery and slave trade in Ethiopia were organized at Addis Ababa University (2011-14), and at the International Conference of Ethiopian Studies in Dire Dawa (2012). In addition, Ethiopia was represented at the "Slavery in Africa" (SLAFCO) international conference, held in Nairobi in 2014; and in the SLAFNET network, funded by the European Union's Horizon 2020 program, which was launched in July 2017. SLAFNET has the objective to facilitate dialogue and collaboration between European and African researchers on the topic of slavery in Africa. As such, the four articles presented in this special issue represent the start of the publication of the results produced by this scientific initiative. They cover several centuries and focus on different regions, putting to good use very different sources, written, printed and oral, Ethiopian and foreign, and they are presented here in a chronological order.

The article of Ayda Bouanga revisits Damot, a little known though powerful polity south of the Blue Nile, between the thirteenth and the sixteenth centuries. Through an attentive reading of the sources, she analyzes the entanglement between gold production and slave production, and she maps the trade routes from Damot to the port of Zaylac. The confrontation of Damot with the expansive Ethiopian Christian state is staged until the final demise of the polity, whose population was in turn raided, enslaved, and subjugated to economic and cultural domination. 
The nineteenth century saw a peak in the production of slaves and their long-distance trade. Moreover, slavery in Ethiopia became an international and diplomatic issue, in particular because of the concern of British abolitionists and the colonial interests of Britain in the region. Alexander Meckelburg and Solomon Gebreyes revisit British colonial archives and present a critical edition of the anti-slavery protocol attached to the "Hewet Treaty," signed by the British and Emperor Yohannəs IV in 1884. Abolitionism and imperialism became intertwined and the "issue of slavery" in Ethiopia became a means for the Christian ruler to position himself in the wider network of colonial politics.

With the article by Peter Garretson, we are taken back to Ethiopian sources. Hakim Wärqənäh played a key role in establishing the Fəqrənna Agälgalot Mahbär (Love and Service Organization), probably the first Ethiopian nongovernmental organization in the 1920s. Composed of progressive members of the Ethiopian elite, including women, this mahbär was dedicated to ending slavery, freeing slaves, and establishing a school for former slaves. Although more efforts would be needed to end slavery in Ethiopia, the mahbär represents an early Ethiopian initiative toward raising consciousness about slavery in the country. The article challenges existing notions of abolition being a "Western" endeavor and brings to attention the Ethiopian abolitionist agenda.

The article by Hagar Salamon illustrates the depth of information that can be found in oral sources located in northwestern Ethiopia. She analyzes the analogy made among slaves, salt, and chili pepper by relying on a collection of proverbs in Amharic, and on the discussion conducted about them with local interviewees. Unique ways to reach deep cultural meanings, these proverbs actually expose the hierarchical relations between masters and slaves and enable the processing of particular contradictions inherent in the system of slavery that has left its mark among the rural people of this region.

These articles present new analyses of the history of slavery and the slave trade. They feed the debate on indigenous Ethiopian slavery by drawing on understudied sources on medieval Ethiopia; they investigate the abolition of the slave trade in the light of late nineteenth century diplomatic history; they offer new insights on Ethiopian initiatives in abolitionism; and they explore 
the cultural depth of the institution of slavery from a folklore perspective. The evidence presented in these articles demonstrates that the study of slavery in Ethiopia represents a major field of knowledge to be pursued.

\section{NOTES}

This project has received funding from the European Union's Horizon 2020 research and innovation program under grant agreement no. 734596.

1. W. E. B. Du Bois, The Suppression of the African Slave-Trade to the United States of America, 1638-1870, Harvard Historical Studies 1 (London: Longmans, Green and Company, 1896); Philip D. Curtin, The Atlantic Slave Trade: A Census (Madison: University of Wisconsin Press, 1969); Orlando Patterson, Slavery and Social Death (Cambridge, MA: Harvard University Press, 1982); Pierre Verger, Flux et reflux de la traite des nègres entre le Golfe de Bénin et Bahia de Todos os Santos du XVIIe au XIXe siècle (Paris: Walter de Gruyter, 1968); Eric Eustace Williams, Capitalism and Slavery (Chapel Hill: University of North Carolina Press, 1944).

2. Frederick Cooper, "The Problem of Slavery in African Studies," Journal of African History 20, no. 1 (1979): 103.

3. We may think of http://www.slavevoyages.org as the most famous example.

4. Paul Lovejoy, Transformations in Slavery: A History of Slavery in Africa, 3rd ed. (Cambridge: Cambridge University Press, 2000); Claude Meillassoux, Anthropologie der Sklaverei, trans. Eva Moldenhauer (Frankfurt-am-Main, Germany: Campus, 1989); Suzanne Miers and Igor Kopytoff, eds., Slavery in Africa: Historical and Anthropological Perspectives (Madison: University of Wisconsin Press, 1979).

5. Roger Botte, "De l'esclavage et du daltonisme dans les sciences sociales. Avantpropos," Journal des africanistes 70, no. 1 (2000): 7-42; Martin A. Klein, Slavery and Colonial Rule in French West Africa, African Studies (Cambridge: Cambridge University Press, 1998); Benedetta Rossi, "African Post-Slavery: A History of the Future," International Journal of African Historical Studies 48, no. 2 (2015): 303-24; Benedetta Rossi, From Slavery to Aid, African Studies 135 (Cambridge: Cambridge University Press, 2015).

6. Bruce S. Hall, A History of Race in Muslim West Africa, 1600-1960, African Studies 115 (Cambridge: Cambridge University Press, 2011); Chouki El Hamel, 
Black Morocco: A History of Slavery, Race, and Islam, African Studies 123 (Cambridge: Cambridge University Press, 2013); Ismael Musah Montana, The Abolition of Slavery in Ottoman Tunisia (Gainesville: University Press of Florida, 2013).

7. Alioum Idrissou, "Pratiques esclavagistes et serviles dans la société lignagière et forestière Béti du Cameroun (XIXe et XXe Siècles): Esquisse d'une Histoire Méconnue," Cahier des Anneaux de La Mémoire. L’Afrique Centrale Atlantique, 2012, 92-117; Henri Médard and Shane Declan Doyle, eds., Slavery in the Great Lakes Region of East Africa (Oxford: James Currey, 2007).

8. Edward A. Alpers, Ivory and Slaves: Changing Pattern of International Trade in East Central Africa to the Later Nineteenth Century (Berkeley and Los Angeles: University of California Press, 1975); Frederick Cooper, Plantation Slavery on the East Coast of Africa (New Haven, CT: Yale University Press, 1977); Frederick Cooper, From Slaves to Squatters: Plantation Labor and Agriculture in Zanzibar and Coastal Kenya, 1890-1925 (New Haven, CT: Yale University Press, 1980).

9. Laura Jeanne Fair, Pastimes and Politics. Culture, Community, and Identity in Post-Abolition Urban Zanzibar, 1890-1945 (Athens: Ohio University Press, 2001); Elisabeth McMahon, Slavery and Emancipation in Islamic East Africa: From Honor to Respectability (Cambridge: Cambridge University Press, 2013).

10. Marie-Pierre Ballarin, "La $43^{\circ}$ tribu': héritage de l'esclavage dans la région de Mombasa (Frere Town) au Kenya,", in Traites et esclavages en Afrique orientale et dans l'océan Indien, eds. Henri Médard, Marie-Laure Derat, Thomas Vernet, and Marie-Pierre Ballarin, Collection Esclavages (Paris: Karthala, 2013), 284-301; Marie-Pierre Ballarin, "L'esclavage en héritage et l'émergence d'une mobilisation sociopolitique au Kenya," Politique africaine, no. 140 (March 2016): 41-59; Samuel Nyanchoga et al., Slave Heritage and Identity at the Kenyan Coast (Nairobi, Kenya: CUEA Press, 2014).

11. Suzanne Miers and Richard L. Roberts, The End of Slavery in Africa (Madison: University of Wisconsin Press, 1988); Lotte Pelckmans and Christine Hardung, eds., "La question de l'esclavage en Afrique : Politisation et mobilisations," Politique africaine no. 140 (March 2016): 5-22; Éric Komlavi Hahonou, "Past and Present African Citizenships of Slave Descent: Lessons from Benin," Citizenship Studies 15, no. 1 (2011): 75-92; Éric Komlavi Hahonou, "The Quest for Honor and Citizenship in Post-Slavery Borgu (Benin)," International Journal of African Historical Studies 48, no. 2 (2015): 325-44. 
12. Patrick Abungu et al., "Heritage, Communities and Opportunities: Shimoni Slave Cave and Wasini Island Heritage Sites (Kenya)," Uganda Journal 53 (2013): 202-21; Stephanie Wynne-Jones and Martin Walsh, "Heritage, Tourism and Slavery at Shimoni: Narrative and Metanarrative on the East African Coast," History in Africa 37 (2010): 247-73.

13. Abdussamad H. Ahmad, "Gojjam: Trade, Early Merchant Capital and the World Economy, 1901-1935" (PhD diss., University of Illinois at Urbana-Champaign, 1986); Mordechai Abir, Ethiopia and the Red Sea: The Rise and Decline of the Solomonic Dynasty and Muslim European Rivalry in the Region (New York: Frank Cass, 2013); Jon R. Edwards, "Slavery, the Slave Trade and the Economic Reorganization of Ethiopia, 1916-1935," African Economic History no. 11 (1982): 3-14; Timothy Fernyhough, "Serfs, Slaves and Shefta: Modes of Production in Southern Ethiopia from the Late Nineteenth Century to 1941" (PhD diss., University of Illinois, 1986); Peter P. Garretson, "Vicious Cycles: Ivory, Slaves, and Arms on the New Maji Frontier," in The Southern Marches of Imperial Ethiopia: Essays in History and Social Anthropology, eds. Donald Donham and Wendy James (Oxford: James Currey, 1986), 196-218; James C. McCann, "Children of the House: Households and Slavery in Ethiopia, 1900-35," in The End of Slavery in Africa, ed. Suzanne Miers and Richard Roberts (Madison: University of Wisconsin Press, 1988), 332-56.

14. Ahmad, "Gojjam: Trade, Early Merchant Capital and the World Economy, 1901-1935"; Abdussamad H. Ahmad, "Trading in Slaves in Bela-Shangul and Gumuz, Ethiopia: Border Enclaves in History, 1897-1938," Journal of African History 40, no. 3 (1999): 433-46; Bahru Zewde, "Relations between Ethiopia and the Sudan on the Western Ethiopian Frontier, 1898-1935" (PhD diss., University of London, 1976); Richard Pankhurst, "The Ethiopian Slave Trade in the Nineteenth and Early Twentieth Centuries: A Statistical Inquiry," in Ethiopian Studies: Papers Read at the 2nd International Conference of Ethiopian Studies (Manchester University, July 1963), ed. Charles Fraser Beckingham and Edward Ullendorff, vol. 1, Journal of Semitic Studies 9 (Manchester: Manchester University Press, 1964), 220-8.

15. A. L. Gardiner, "The Law of Slavery in Abyssinia," Journal of Comparative Legislation and International Law 15, no. 4 (1933): 180-202; Getatchew Haile, "From the Markets of Damot to that of Bärara: A Note on Slavery in Medieval Ethiopia," Paideuma 27 (1981): 173-80; Habtamu Tegegne, “The Edict of King 
Gälawdéwos Against the Illegal Slave Trade in Christians: Ethiopia, 1548," Medieval Globe 2, no. 2 (2016), http://scholarworks.wmich.edu/tmg/vol2/iss2/5; Richard Pankhurst, "Slavery and Emancipation in Traditional Ethiopia: The Role of the Fetha Nagast, or Laws of the Kings," African and Asian Studies 10, no. 1 (2011): 32-40.

16. Bosha Bombe, "Reclaiming Lost Identity. Redemption of Slave Descendants among the Ganta," in Creating and Crossing Boundaries in Ethiopia: Dynamics of Social Categorization and Differentiation, ed. Susanne Epple (Münster-Berlin, Germany: LIT, 2014), 73-90; Marie-Laure Derat, “Chrétiens et musulmans d'Ethiopie face à la traite et à l'esclavage aux XVe et XIXe siècles," in Traites et esclavages en Afrique orientale et dans l'océan Indien, eds. Henri Médard, MarieLaure Derat, Thomas Vernet, and Marie-Pierre Ballarin. Collection Esclavages (Paris: Karthala, 2013), 121-48; Alexander Meckelburg, "Slavery, Emancipation, and Memory: Exploratory Notes on Western Ethiopia," International Journal of African Historical Studies 48, no. 2 (2015): 345-62; Christine Whyte, “Everyone Knows That Laws Bring the Greatest Benefits to Mankind': The Global and Local Origins of Anti-Slavery in Abyssinia, 1880-1942," Slavery and Abolition 35, no. 4 (2014): 652-69.

17. Bombe, "Reclaiming Lost Identity"; Wendy James, "Perceptions from an African Slaving Frontier," in Slavery and Other Forms of Unfree Labour in Africa, ed. Léonie Archer (New York: Routledge, 1988), 113-40; Meckelburg, "Slavery, Emancipation, and Memory"; Hagar Salamon, "Slavery among the 'Beta-Israel' in Ethiopia: Religious Dimensions of Inter-group Perceptions," Slavery and Abolition 15, no. 1 (1994): 72-88; Joachim Theis, Nach der Razzia: Ethnographie und Geschichte der Koma, Sudanesische Marginalien 3 (Munich, Germany: Trickster, 1995).

18. Rossi, "African Post-Slavery," 303.

19. Henri Médard, "La traite et l'esclavage en Afrique orientale et dans l'océan Indien: une historiographie éclatée," in Traites et esclavages en Afrique orientale et dans l'océan Indien, eds. Henri Médard, Marie-Laure Derat, Thomas Vernet, and Marie-Pierre Ballarin. Collection Esclavages. (Paris: Karthala, 2013), 31-63.

20. Ibid., 63.

21. Richard Pankhurst et al., "Slavery," Encyclopaedia Aethiopica (Wiesbaden, Germany: Harrassowitz, 2010).

22. Ibid., 673 . 
23. Ibid.

24. Omar H. Ali, Malik Ambar: Power and Slavery Across the Indian Ocean (Oxford: Oxford University Press, 2016); Edward A. Alpers, The Indian Ocean in World History (Oxford: Oxford University Press, 2014); Shihan de Jayasuriya and Richard Pankhurst, eds., The African Diaspora in the Indian Ocean (Trenton, NJ: Africa World Press, 2003).

25. Ababu Minda Yimene, An African Indian Community in Hyderabad: Siddi Identity, Its Maintenance and Change (Göttingen, Germany: Cuvillier Verlag, 2004); Amy Catlin-Jairazbhoy and Edward A. Alpers, eds., Sidis and Scholars: Essays on African Indians (Trenton, NJ: Red Sea Press, 2004).

26. Abdussamad H. Ahmad, "Ethiopian Slave Exports at Matamma, Massawa and Tajura, c. 1830-1885," in The Economics of the Indian Ocean Slave Trade in the Nineteenth Century, ed. William Gervase Clarence-Smith (New York: Routledge, 2013), 93-102.

27. Jonathan Miran, "From Bondage to Freedom on the Red Sea Coast: Manumitted Slaves in Egyptian Massawa, 1873-1885," Slavery and Abolition 34, no. 1 (2013): 3.

28. Sandy Shell, "The Oromo Children of Lovedale, South Africa: A Prosopography of African Slavery and Its Long-Term After-Effects," SSRN Scholarly Paper (Rochester, NY: Social Science Research Network, 2013) ; Wolbert Smidt, "Quellenübersicht zur Biographie des ehemaligen Sklaven und ersten OromoBibelübersetzers Christian Rufo," Afrikanistische Arbeitspapiere 67 (2001): 181-98; Wolbert Smidt, "The Role of the Former Oromo Slave Pauline Fathme in the Foundation of the Protestant Oromo Mission," in Ethiopia and the Missions: Historical and Anthropological Insights into the Missionary Activities in Ethiopia, eds. Verena Böll, Andreu Martínez d'Alòs-Moner, and Steven Kaplan (Münster, Germany: LIT, 2005), 77-98.

29. Ahmad, “Gojjam," 159.

30. Médard, "La plus ancienne et la plus récente des traites," 48-52.

31. Charles Johnston, Travels in Southern Abyssinia, through the Country of Adal to the Kingdom of Shoa, vol. 1 (London: J. Madden and Co., 1844), 51.

32. Walter Chichele Plowden, Travels in Abyssinia and the Galla Country: With an Account of a Mission to Ras Ali in 1848, ed. Trevor Chichele Plowden (London: Longmans, Green, and Co., 1868), 3.

33. Derat, "Chrétiens et musulmans d'Ethiopie face à la traite et à l'esclavage aux XVe et XIXe siècles," 147. 
34. Pankhurst et al., "Slavery," 679.

35. Friedrich J. Bieber, Kaffa: Ein Altkuschitisches Volkstum in Inner-Afrika; Nachrichten über Land und Volk, Brauch und Sitte der Kaffitscho oder Gouga und das Kaiserreich Kaffa, vol. 1, Internationale Sammlung Ethnologischer Monographien (Münster, Germany: Verlag der Aschendorffschen Verlagsbuchhandlung, 1920), 144; Tekalign W. Mariam, "The Slave Trade in the Economy of Jimma," in Proceedings of the Eighth International Conference of Ethiopian Studies, ed. Taddese Beyene, vol. 1 (Addis Ababa, Ethiopia: Institute of Ethiopian Studies, 1989), 310.

36. Ulrich Braukämper, Fandaanano: The Traditional Socio-Religious System of the Hadiyya in Southern Ethiopia, vol. 80, Aethiopistische Forschungen (Wiesbaden, Germany: Harrassowitz, 2014), 79.

37. Quoted in Henri Médard, "Introduction," in Traites et esclavages en Afrique orientale et dans l'océan Indien, eds. Henri Médard, Marie-Laure Derat, Thomas Vernet, and Marie-Pierre Ballarin, 1-30. Collection Esclavages. (Paris: Karthala, 2013), 23.

38. Ibid., 124-32.

39. Habtamu Mengistie Tegegne, "Land Tenure and Agrarian Social Structure in Ethiopia, 1636-1900" (PhD Dissertation, University of Illinois, 2011).

40. Donald Donham, "Old Abyssinia and the New Ethiopian Empire: Themes in Social History," in The Southern Marches of Imperial Ethiopia: Essays in History and Social Anthropology, ed. Donald Donham and Wendy James (Cambridge: Cambridge University Press, 1986), 3-48.

41. Zewde, "Relations between Ethiopia and the Sudan on the Western Ethiopian Frontier, 1898-1935," 50.

42. Garretson, "Vicious Cycles: Ivory, Slaves, and Arms."

43. Ahmad, "Trading in Slaves in Bela-Shangul and Gumuz, Ethiopia"; Alexander Meckelburg, "From 'Subject to Citizen?' History, Identity and Minority Citizenship: The Case of the Mao and Komo of Western Ethiopia” (PhD diss., Universität Hamburg, 2017).

44. Ahmad, "Trading in Slaves in Bela-Shangul and Gumuz, Ethiopia."

45. Zewde, "Relations between Ethiopia and the Sudan on the Western Ethiopian Frontier, 1898-1935," 50.

46. Donald Crummey, “Abyssinian Feudalism," Past and Present no. 89 (1980): 127.

47. Ibid., 161. 
48. Moses I. Finley, Ancient Slavery and Modern Ideology, ed. Brent Shaw (Princeton, NJ: Markus Wiener, 1998).

49. Fernyhough, "Serfs, Slaves and Shefta"; Guluma Gemeda, "The Rise of Coffee and the Demise of Colonial Autonomy: The Oromo Kingdom of Jimma and Political Centralization in Ethiopia," Northeast African Studies 9, no. 3 (2002): 51-74; Herbert S. Lewis, Jimma Abba Jifar, an Oromo Monarchy: Ethiopia, 1830-1932 (Madison: University of Wisconsin Press, 1965); Mariam, “The Slave Trade in the Economy of Jimma."

50. Fernyhough, "Serfs, Slaves and Shefta," 173.

51. Mariam, “The Slave Trade in the Economy of Jimma," 314.

52. Ibid., 315. Emphasis in original.

53. Gemeda, "The Rise of Coffee and the Demise of Colonial Autonomy," 68.

54. Edwards, "Slavery, the Slave Trade and the Economic Reorganization of Ethiopia, 1916-1935."

55. Ibid., 4.

56. Guluma Gemeda, "Subsistence, Slavery and Violence in Lower Omo Valley, ca. 1898-1940s," Northeast African Studies 12, no. 1 (1990): 5-19.

57. Suzanne Miers, "Britain and the Suppression of Slavery in Ethiopia," Slavery and Abolition 18, no. 3 (1997): 267.

58. Jean Allain, "Slavery and the League of Nations: Ethiopia as a Civilised Nation," Journal of the History of International Law 8 (2006): 213-44; Sterling Joseph Coleman, "Gradual Abolition or Immediate Abolition of Slavery? The Political, Social and Economic Quandary of Emperor Haile Selassie I," Slavery and Abolition 29, no. 1 (2008): 65-82; Antoinette Iadarola, “Ethiopia's Admission into the League of Nations: An Assessment of Motives," International Journal of African Historical Studies 8, no. 4 (1975): 601-22; Alain Rouaud, Le négus contre l'esclavage: les édits abolitionnistes du ras Täfäri : contexte et circonstances (Paris: Aresae, 1998).

59. Bahru Zewde, Pioneers of Change in Ethiopia: The Reformist Intellectuals of the Early Twentieth Century, Eastern African Studies (Oxford: James Currey, 2002); Peter P. Garretson, A Victorian Gentleman \& Ethiopian Nationalist: The Life and Times of Hakim Wärqenäh, Dr. Charles Martin (Oxford: James Currey, 2012); Whyte, "Everyone Knows That Laws Bring the Greatest Benefits to Mankind." 60. Tegegne, "The Edict of King Gälawdéwos."

61. Henri Médard, "La plus ancienne et la plus récente des traites: panorama de la 
traite et de l'esclavage en Afrique orientale et dans l'océan Indien," in Traites et esclavages en Afrique orientale et dans l'océan Indien, eds. Henri Médard, MarieLaure Derat, Thomas Vernet, and Marie-Pierre Ballarin. Collection Esclavages. (Paris: Karthala, 2013), 77

62. Timothy Fernyhough, "Slavery and the Slave Trade in Southern Ethiopia in the 19th Century," Slavery and Abolition 9, no. 3 (1988): 103-30.

63. Coleman, "Gradual Abolition or Immediate Abolition of Slavery?," 76.

64. Aberra Jembere, An Introduction to the Legal History of Ethiopia, 1434-1974 (Münster, Germany: LIT, 2000), 235.

65. Miers, "Britain and the Suppression of Slavery in Ethiopia," 237.

66. Fernyhough, "Slavery and the Slave Trade in Southern Ethiopia in the 19th Century."

67. Perham's chapter on slavery was written in collaboration with De Halpert; cp. Margery Perham, The Government of Ethiopia (London: Faber and Faber, 1948).

68. Miers, "Britain and the Suppression of Slavery in Ethiopia," 272.

69. McCann, "Children of the House: Households and Slavery in Ethiopia, 1900-35," 350.

70. G. C. Baravelli, Das letzte Bollwerk der Sklaverei: Abessinien (Rome: Società Editrice di Novissima, 1935).

71. Timothy Derek Fernyhough, Serfs, Slaves and Shifta: Modes of Production in PreRevolutionary Ethiopia (Addis Ababa, Ethiopia: Shama Books, 2010), 224.

72. Meckelburg, “From 'Subject to Citizen?,” 139.

73. Igor Kopytoff, “Slavery," Annual Review of Anthropology 11 (1982): 207-30.

74. James, "Perceptions from an African Slaving Frontier," 113.

75. Laury Belrose, “Quand l'histoire rencontre la mémoire: une appréhension de la traite et de l'esclavage en Ethiopie à travers des témoignages, $20^{\circ}-21^{\circ}$ siècles," in Traites et esclavages en Afrique orientale et dans l'océan Indien, eds. Henri Médard, Marie-Laure Derat, Thomas Vernet, and Marie-Pierre Ballarin. Collection Esclavages (Paris: Karthala, 2013), 149-67; Bombe, "Reclaiming Lost Identity. Redemption of Slave Descendants among the Ganta"; Arnaud Kruczynski, "La traite des esclaves et le Guragé au XIXe siècle: la création d'une identité régionale dans le sud-ouest éthiopien," in Traites et esclavages en Afrique orientale et dans l'océan Indien, eds. Henri Médard, Marie-Laure Derat, Thomas Vernet, and Marie-Pierre Ballarin, Collection Esclavages (Paris: Karthala, 2013), 169-96; Meckelburg, "Slavery, Emancipation, and Memory." 
76. Martin A. Klein, "Studying the History of Those Who Would Rather Forget: Oral History and the Experience of Slavery," History in Africa 16 (1989): 209-17; Marie Rodet, "Listening to the History of Those Who Don't Forget," History in Africa 40, Anniversary Issue (2013): 27-29.

77. Catherine Besteman, "Public History and Private Knowledge: On Disputed History in Southern Somalia," Ethnohistory 40, no. 4 (1993): 567.

78. Kruczynski, "La traite des esclaves et le Guragé."

79. Derat, "Chrétiens et musulmans d'Ethiopie face à la traite et à l'esclavage aux XVe et XIXe siècles," 130.

80. Bombe, "Reclaiming Lost Identity. Redemption of Slave Descendants among the Ganta."

81. Belrose, "Quand l'histoire rencontre la mémoire," 166.

82. Donald Crummey, Land and Society in the Christian Kingdom of Ethiopia: From the Thirteenth to the Twentieth Century (Urbana: University of Illinois Press, 2000), 259.

83. See, for example, the pamphlet by Jamaican-American author and historian Joel Rogers, The Real Facts about Ethiopia (Baltimore, MD: Black Classic Press, 1936).

\section{ABOUT THE AUTHORS}

Giulia Bonacci is a historian, and researcher at the Institute of Research for Development (IRD). She is currently posted at University Nice Sophia Antipolis. She is a member of the ERC funded project SLAFNET (Slavery in Africa: A Dialogue between Africa and Europe). Her book Exodus! Heirs and Pioneers, Rastafari Return to Ethiopia was translated and published by The University of the West Indies Press in Kingston, Jamaica (2015). It received the IndieFab Book of the Year Award in 2015 and the Choice Outstanding Academic Title in 2017. She is a specialist of Ethiopia and of the English-speaking Caribbean, and her work on slavery and its legacies, diasporas in Ethiopia, and Pan Africanism is grounded on archival, print, and oral history research. She publishes regularly in scientific journals (International Journal of African Historical Studies, Cahiers d'études africaines, Revue européenne des migrations internationales, African Diaspora, Annales d'Ethiopie, New West Indian Guide, and others) and in the cultural media. 
Alexander Meckelburg is a postdoctoral researcher at the Hiob Ludolf Centre for Ethiopian Studies and is also currently visiting scholar and lecturer at the Department for Social Sciences at the Catholic University of Eastern Africa. He is a member of the ERC funded project SLAFNET (Slavery in Africa: A Dialogue between Africa and Europe). Alexander holds a PhD in Ethiopian studies from the University of Hamburg. He was an editorial assistant for the Encyclopaedia Aethiopica (2009-2014) and a research fellow at the Hiob Ludolf Centre for Ethiopian Studies (2014-2016). His research focuses on the abolition and legacies of slavery in Ethiopia and Eastern Africa, as well as on the ethnohistory of western Ethiopia and the borderlands with the Sudan. 